\title{
PROSES MEMBANGUN PENGETAHUAN KONSEPTUAL PADA SISWA KELAS VIII DALAM PEMBELAJARAN MATEMATIKA DI SMP NEGERI 1 KUDUS
}

\author{
Nova Ayu Arisjanti ${ }^{1}$, Imam Sujadi ${ }^{2}$, Tri Atmojo Kusmayadi ${ }^{3}$ \\ ${ }^{1,2,3}$ Prodi Magister Pendidikan Matematika, PPs Universitas Sebelas Maret Surakarta
}

\begin{abstract}
The objective of this research is to describe the process of conceptual knowledge building of the students in Grade VIII in Mathematics learning at State Junior High School 1 of Kudus. This research used a qualitative case study method. The subjects of the research were three students in Grade VIII of the school with the high, medium, and low academic abilities respectively. The subjects of the research were chosen by using the purposive sampling technique. The data of the research were gathered through passive participatory observations. All of the learning activities were documented by taping them with handy camera. Based on data analysis of the three students in Grade VIII with the high, medium, and low academic abilities respectively in mathematics learning at the cube and cuboid elements at State Junior High School 1 of Kudus are as follows. (1) The process of conceptual knowledge building of the subject of the research with the low academic ability. Initially the knowledge associated with submitted materials teachers are still global. The information and knowledge obtained from doing the exercises, through: (a) visualizing the shape of cube and cuboid into the other shape to identify the elements; (b) making the relation and category classification between cube and cuboid. Doing the other activity, like: (a) learning the note book, handbook, and student's work sheet; (b) using the complete note book as reference in the learning; (c) attending courses. (2) The process of conceptual knowledge building of the subject of the research with the medium academic ability. Initially knowledge obtained from teacher in the mathematics learning still global. The information and knowledge obtained from doing the exercises, through: (a) making the relation and category classification between cube and cuboid; (b) identifying the side of shape from cuboid through example. Doing the other activity, like: (a) relearning the material; (b) using material from explanation the teacher as reference in the learning; (c) giving certain signs if there are differences in the contents of the learning materials of the books learned; (d) doing the different exercises with example from the teacher; (e) attending courses. (3) The process of conceptual knowledge building of the subject of the research with the high academic ability. Initially acquired knowledge not as detailed as what the teachers explained. The information and knowledge obtained from doing the exercises, through: (a) discussion; (b) visualizing the shape of cube and cuboid into the other shape to indentify the elements; (c) determining criteria of classification the cube and cuboid. Doing the other activity, like: (a) reading the material; (b) doing the exercises from the formula and solution in the handbook; (c) attending courses.
\end{abstract}

Keywords: the process of knowledge building, conceptual knowledge, and mathematics learning.

\section{PENDAHULUAN}

Pengalaman dalam membangun pengetahuan tentang konsep diperlukan agar siswa memiliki struktur konsep yang berguna dalam menganalisis dan mengevaluasi suatu permasalahan. Disadari atau tidak, siswa mempunyai cara yang berbeda dalam memahami suatu konsep. Seorang guru matematika yang mengajar di kelas sering menjumpai siswa yang mempunyai pemahaman berbeda tentang pengetahuan yang diperoleh dan pengetahuan yang dipelajarinya, padahal siswa-siswa belajar dalam 
lingkungan sekolah, guru, dan bahkan buku panduan yang sama. Hal ini menunjukkan bahwa pengetahuan tidak begitu saja dapat ditransfer dari guru ke siswa dalam bentuk tertentu, melainkan siswa harus membentuk sendiri pengetahuan itu dalam pikirannya masing-masing sehingga pengetahuan tentang sesuatu tersebut dapat terbentuk pada siswa. Berdasarkan penelitian yang dilakukan oleh Sultan et al., (2011) ditemukan adanya aspek yang berbeda dari masing-masing hasil belajar siswa dengan menggunakan pemikiran kreatif berbasis konstruktivis untuk membangun pengetahuan siswa dalam proses belajar mengajar. Senada dengan hasil penelitian tersebut, Powell dan Kalina (2009) menjelaskan bahwa sebuah kelas yang efektif bergantung bagaimana guru dan siswa berkomunikasi secara optimal, penggunaan strategi konstruktivis, alat, dan praktik.

Adanya perbedaan pola pikir pada diri siswa dalam membangun pengetahuan tentang suatu konsep mengharuskan siswa memiliki sikap dan perilaku belajar yang kondusif serta memanfaatkan keterampilan berpikir. Hal tersebut membantu siswa untuk memperluas wawasan dan menghaluskan pengetahuan barunya, sehingga tujuan terpenting dalam belajar adalah menggunakan pengetahuan dengan cara bermakna. Perolehan pengetahuan konseptual yang benar adalah proses yang sulit di banyak domain, karena banyak konsep yang secara rutin digunakan dalam bahasa sehari-hari memiliki makna berbeda secara formal (Nievelstein et al., 2010: 25). Beberapa penelitian yang mendukung pentingnya membangun pengetahuan konseptual siswa dalam pembelajaran, diantaranya penelitian yang dilakukan Emereole (2008), hasil penelitian menunjukkan bahwa tidak ada hubungan antara pengetahuan konseptual siswa dari proses dan variabel demografi jenis kelamin, usia, program studi, tahun studi, profesi yang diinginkan, program sains sekolah menengah yang diikuti, sekolah, dan lingkungan rumah. Kemampuan mereka untuk memberikan definisi konseptual yang benar tidak menguatkan tingkat keakraban mereka dengan proses sains (proses ilmiah). Disarankan bahwa pendidik ilmu di semua tingkat harus memastikan bahwa siswa mereka memperoleh dengan baik pengetahuan konseptual dan praktis dari proses ilmiah. Dalam penelitian berikutnya Emereole (2009), menemukan bahwa para guru sains tidak memiliki pengetahuan konseptual yang memadai tentang proses ilmu pengetahuan untuk membantu siswa dalam memahami suatu konsep dengan cara yang berarti.

Penelitian ini bertujuan untuk mendeskripsikan proses membangun pengetahuan konseptual pada siswa kelas VIII dalam pembelajaran matematika di SMP Negeri 1 Kudus pada materi unsur-unsur kubus dan balok. 


\section{METODE PENELITIAN}

Penelitian dilaksanakan di kelas VIII SMP Negeri 1 Kudus. Jenis penelitian ini adalah penelitian kualitatif studi kasus. Subjek penelitian adalah tiga orang siswa kelas VIII SMP Negeri 1 Kudus dengan masing-masing kemampuan akademik tinggi, sedang, dan rendah. Pemilihan subjek penelitian dilakukan secara purposive sampling. Pengambilan data dilakukan secara natural setting. Peneliti menggunakan observasi partisipasi pasif. Peneliti mendokumentasikan kegiatan pembelajaran yang menggunakan media audio visual berupa handycam. Observasi pada pelaksanaan pembelajaran matematika di kelas VIII SMP Negeri 1 Kudus dilakukan sebanyak 4 kali. Pada setiap observasi, peneliti melakukan wawancara kepada subjek penelitian sebanyak 2 kali, sehingga diperoleh 8 hasil wawancara dari setiap subjek penelitian. Wawancara pertama dilakukan setelah pembelajaran berlangsung dan wawancara kedua dilakukan 2 hari setelah wawancara pertama. Setelah diperoleh 4 hasil observasi terkait pelaksanaan pembelajaran dan 8 data hasil wawancara dari setiap subjek penelitian, peneliti memilih 2 data hasil observasi dan 4 data hasil wawancara dari setiap subjek penelitian yang memberikan data terlengkap. Peneliti juga melakukan konfirmasi data hasil wawancara kepada setiap subjek penelitian. Konfirmasi ini dilakukan karena masih ada data yang diperlukan untuk analisis yang belum diperoleh pada saat wawancara pertama dan kedua baik pada materi unsur-unsur kubus maupun materi unsur-unsur balok. Dari data yang dipilih tersebut, kemudian peneliti melakukan analisis secara mendalam. Proses analisis data dimulai dengan mengkaji seluruh data yang dipilih dari hasil rekaman pelaksanaan proses pembelajaran matematika dan hasil wawancara. Penelitian ini mengikuti tiga tahapan analisis data kualitatif sebagaimana digariskan oleh Miles dan Huberman, yaitu reduksi data, penyajian data, dan penarikan kesimpulan. Uji kredibilitas dalam penelitian ini dilakukan menggunakan membercheck.

\section{HASIL PENELITIAN DAN PEMBAHASAN}

Berdasarkan hasil penelitian dan analisis data yang telah dilakukan, secara keseluruhan diperoleh hasil bahwa tiga orang subjek penelitian yang merupakan siswa kelas VIII Sekolah Menengah Pertama (SMP) Negeri 1 Kudus dengan masing-masing kemampuan akademik tinggi, sedang, dan rendah memiliki pengetahuan yang berbeda dalam menangkap materi pelajaran berkaitan dengan konsep-konsep pada materi unsurunsur kubus dan balok yang disampaikan oleh guru pada saat proses pembelajaran matematika berlangsung. Dengan perbedaan pengetahuan yang dimiliki oleh masingmasing subjek penelitian tersebut, membuat masing-masing subjek penelitian mempunyai 
cara yang berbeda untuk mengembangkan pengetahuannya sehingga hasil yang diperoleh masing-masing subjek penelitian dengan kemampuan akademik tinggi, sedang, dan rendah juga berbeda tergantung proses yang dilakukannya. Berikut diuraikan pengetahuan dan cara membangun pengetahuan yang dilakukan masing-masing subjek penelitian dalam memahami materi unsur-unsur kubus dan balok.

\section{Proses Membangun Pengetahuan Konseptual Subjek ABS, Sebagai Subjek Penelitian dengan Kemampuan Akademik Rendah}

Berdasarkan penjelasan guru pada pelaksanaan pembelajaran berkaitan dengan materi unsur-unsur kubus dan 2 kali hasil wawancara yang dilakukan kepada subjek ABS, diketahui adanya perbedaan antara penjelasan dari guru dan uraian yang disampaikan subjek ABS ketika menjelaskan tentang unsur-unsur dalam sebuah kubus. Pada wawancara pertama ini, subjek ABS mengemukakan unsur-unsur dalam sebuah kubus yaitu memiliki 6 buah sisi, 12 buah rusuk, 8 buah titik sudut, memiliki 12 buah diagonal bidang, dan 4 buah diagonal ruang. Uraian tersebut sama dengan penjelasan guru pada saat proses pembelajaran berlangsung.

Pada wawancara kedua, pengetahuan yang dimiliki subjek ABS berkaitan dengan konsep-konsep pada materi unsur-unsur kubus yang meliputi titik sudut, sisi, rusuk, diagonal sisi, diagonal ruang, dan bidang diagonal semakin bertambah luas. Hal tersebut ditunjukkan dengan uraian yang disampaikan subjek ABS dalam melengkapi uraian yang sebelumnya telah dipaparkan pada wawancara pertama. Pada wawancara kedua ini subjek ABS menyatakan bahwa sebuah kubus mempunyai 6 buah sisi, 12 buah rusuk, 8 buah titik sudut, 12 buah diagonal bidang, 4 buah diagonal ruang, dan 6 buah bidang diagonal.

Perbedaan uraian yang disampaikan subjek ABS pada wawancara pertama dan wawancara kedua terletak pada bidang diagonal yang merupakan salah satu unsur-unsur dalam kubus dan baru diuraikan oleh subjek ABS pada wawancara kedua. Diketahui bahwa subjek ABS mengetahui adanya bidang diagonal dalam sebuah kubus melalui proses mempelajari kembali materi pelajaran di luar jam sekolah. Tidak hanya mempelajari kembali materi pelajaran dengan cara membaca catatan pelajaran, namun subjek ABS juga membaca referensi lain berupa LKS dan buku paket dari sekolah sebagai sumber belajar. Subjek ABS mengerjakan soal-soal latihan yang merupakan tugas dari guru, namun jika soal tersebut bukanlah tugas maka subjek ABS tidak mengerjakannya dan hanya membacanya saja. Subjek ABS juga mengikuti les di luar jam sekolah untuk lebih mendalami materi pelajaran karena menurut subjek ABS di tempat les tersebut subjek ABS mendapatkan tambahan pengetahuan yang tidak diperolehnya ketika di sekolah. Beberapa hal lain yang dilakukan subjek ABS untuk lebih memahami 
materi adalah dengan: (1) memvisualisasikan bentuk kubus ke dalam bentuk benda lain di lingkungan sekitar untuk mengidentifikasi unsur-unsurnya salah satunya yaitu sisi; (2) mengkategorikan sebuah benda termasuk sebuah kubus menggunakan bentuk sisinya; (3) subjek ABS membaca beberapa referensi lain seperti buku paket dan LKS untuk lebih memahami suatu materi pelajaran; dan (4) subjek ABS menggunakan buku acuan yang paling lengkap dari semua buku acuan yang dimilikinya sebagai sumber belajar.

Adanya proses belajar tersebut, menunjukkan bahwa subjek ABS tidak langsung menerima dan membenarkan materi pelajaran yang disampaiakan guru, namun setelah proses pembelajaran berlangsung subjek ABS berusaha mencari pengetahuanpengetahuan baru yang bisa melengkapi pengetahuan yang diperolehnya dari penjelasan guru dengan berbagai cara.

Pada materi unsur-unsur balok, subjek ABS sebagai subjek penelitian dengan kemampuan akademik rendah memiliki pengetahuan yang berbeda daripada ketika mempelajari materi unsur-unsur kubus. Hal tersebut ditunjukkan dengan uraian subjek ABS pada 2 kali wawancara yaitu wawancara pertama dan wawancara kedua yang cenderung sama. Berdasarkan uraian guru pada pembelajaran matematika materi unsurunsur balok, pada wawancara pertama subjek ABS menyatakan bahwa unsur-unsur dalam sebuah balok antara lain mempunyai 6 buah sisi, 12 buah rusuk, 8 buah titik sudut, 12 buah diagonal bidang, 4 buah diagonal ruang, dan 6 buah bidang diagonal. Pada wawancara kedua, subjek ABS mengemukakan bahwa sebuah balok mempunyai 6 buah sisi, 12 buah rusuk, 8 buah titik sudut, 12 buah diagonal bidang, 4 buah diagonal ruang, dan 6 buah bidang diagonal.

Dilihat dari uraian subjek ABS pada 2 kali kesempatan wawancara tersebut, diketahui bahwa pengetahuan subjek ABS berkaitan dengan materi unsur-unsur balok sudah baik. Secara keseluruhan cara yang dilakukan subjek ABS untuk lebih mengembangkan pengetahuannya berkaitan dengan materi unsur-unsur balok yang disampaikan guru pada proses pembelajaran matematika adalah: (1) dalam mempelajari materi berkaitan dengan unsur-unsur balok ini, subjek ABS mempunyai pemikiran bahwa balok mempunyai unsur-unsur yang sama dengan yang dimiliki oleh sebuah kubus; (2) subjek ABS mampu membuat hubungan antara kubus dan balok dengan menganggap keduanya mempunyai unsur yang sama.

Berbagai cara memperoleh pengetahuan yang dilakukan oleh subjek ABS tersebut, senada dengan pendapat yang dikemukakan oleh Francis Bacon (dalam Notoatmodjo, 2010: 10-18) bahwa dalam memperoleh kesimpulan dilakukan dengan mengadakan observasi langsung dan membuat pencatatan-pencatatan terhadap semua fakta sehubungan dengan objek yang diamati. Selain itu, dengan adanya kegiatan 
mempelajari kembali materi pelajaran yang dilakukan subjek ABS menunjukkan bahwa subjek ABS berusaha mencari sumber referensi lain baik internal maupun eksternal yang bisa mendukung pengetahuannya terhadap materi pelajaran. Sumber pemerolehan pengetahuan tersebut, sesuai dengan penjelasan Stapleton (2003: 43) bahwa membangun pengetahuan dimulai dengan mencari informasi-informasi yang dibutuhkan.

\section{Proses Membangun Pengetahuan Konseptual Subjek DHS, Sebagai Subjek Penelitian dengan Kemampuan Akademik Sedang}

Berdasarkan penjelasan guru pada pelaksanaan pembelajaran berkaitan dengan materi unsur-unsur kubus dan 2 kali hasil wawancara yang dilakukan kepada subjek DHS, diketahui adanya perbedaan antara penjelasan dari guru dengan uraian yang disampaikan subjek DHS ketika menjelaskan tentang unsur-unsur dalam sebuah kubus. Pada wawancara pertama, subjek DHS menyatakan bahwa unsur-unsur kubus antara lain mempunyai 12 buah rusuk, 6 buah sisi, 8 buah titik sudut, 6 buah diagonal ruang, dan 12 diagonal sisi. Sementara pada wawancara kedua, subjek DHS menyatakan bahwa unsurunsur kubus antara lain mempunyai rusuk 12 buah, sisi 6 buah, titik sudut 8 buah, diagonal ruang 4 buah, diagonal sisi 12 buah, dan bidang diagonal 6 buah.

Perbedaan uraian yang disampaikan subjek DHS pada wawancara pertama dan kedua terletak pada perubahan jumlah diagonal ruang. Pada wawancara pertama subjek DHS menyatakan ada 6 buah diagonal ruang, kemudian pada wawancara kedua diubah menjadi berjumlah 4 buah. Selain itu, subjek DHS juga mengemukakan unsur baru yaitu bidang diagonal sebagai salah satu unsur dari sebuah kubus. Dengan adanya perbedaan uraian yang disampaikan subjek DHS pada 2 kali kesempatan wawancara tersebut, diketahui bahwa subjek DHS melakukan proses membangun pengetahuan berkaitan dengan materi unsur-unsur kubus. Cara yang dilakukan subjek DHS dalam proses membangun pengetahuan cukup beragam, mulai dari mempelajari kembali materi pelajaran yang diperolehnya dari pembelajaran di sekolah sampai mengerjakan soal-soal latihan. Namun sebagai acuan belajar, subjek DHS masih terfokus pada materi yang disampaikan guru. Ketika subjek DHS menemukan perbedaan isi materi yang disampaikan guru dengan yang dipelajarinya, subjek DHS hanya memberikan tanda untuk menunjukkan perbedaan dan kelengkapan dari masing-masing buku yang digunakannya sebagai sumber belajar. Subjek DHS juga mengikuti les di luar jam sekolah, dengan adanya les tersebut subjk DHS mempelajari kembali materi yang sebelumnya sudah dijelaskan oleh guru pada saat proses pembelajaran di sekolah.

Pada materi unsur-unsur balok, subjek DHS sebagai subjek penelitian dengan kemampuan akademik sedang mempunyai pengetahuan yang cukup luas berkaitan 
dengan konsep-konsep pada materi unsur-unsur balok yang diajarkan guru saat pembelajaran matematika. Pada 2 kali wawancara yang dilakukan dalam waktu berbeda yakni wawancara pertama dilakukan setelah pembelajaran, sementara wawancara kedua dilakukan dengan memberikan jeda waktu selama 2 hari terhitung sejak pembelajaran berkaitan dengan materi unsur-unsur balok tersebut dilakukan oleh guru. Dari penjelasan guru tersebut, pada wawancara pertama subjek DHS menyatakan bahwa unsur-unsur balok antara lain rusuknya 12 , sisinya 6 , titik sudutnya 8 , diagonal ruang 4 , diagonal sisi 12, dan bidang diagonalnya 6. Pada wawancara kedua, subjek DHS menyatakan bahwa unsur-unsur dalam sebuah balok adalah memiliki rusuk 12 , sisinya 6 , titik sudutnya 8 , diagonal ruang 4, diagonal sisi 12, dan bidang diagonalnya 6 .

Hasil wawancara pertama dan kedua menunjukkan bahwa subjek DHS menyampaikan uraian yang sama berkaitan dengan konsep-konsep pada materi unsurunsur balok. Secara garis besar materi unsur-unsur kubus dan unsur-unsur balok memiliki isi materi bahkan konsep yang hampir sama, hal tersebut digunakan subjek DHS sebagai jembatan dalam mempelajari materi unsur-unsur balok sehingga subjek DHS tidak mengalami kesulitan ketika mempelajari materi tersebut.

Secara keseluruhan cara yang dilakukan subjek ABS untuk lebih mengembangkan pengetahuannya berkaitan dengan materi unsur-unsur balok yang disampaikan guru pada proses pembelajaran matematika adalah: (1) subjek DHS memvisualisasikan bentuk balok ke dalam bentuk benda lain di lingkungan sekitar kemudian mengidentifikasi unsur-unsurnya terutama sisi pada balok; (2) subjek DHS mengembangkan pengetahuan melalui proses mempelajari kembali materi yang telah disampaikan oleh guru dan membaca referensi lain yang mendukung. Buku referensi lain yang dibaca subjek DHS adalah buku paket dan LKS yang diperolehnya dari sekolah. Dalam materi unsur-unsur kubus ini, subjek DHS hanya membaca materi pelajaran dikarenakan tidak terdapat banyak latihan soal yang menuntut pemecahan masalah dalam materi tersebut; (3) tidak semua materi pelajaran yang dipelajari ulang oleh subjek DHS bisa dimengerti, subjek DHS mengalami kesulitan ketika menemukan soal-soal yang menuntut pemecahan masalah pada suatu materi pelajaran. Untuk mengatasi kesulitan tersebut, subjek DHS mencoba mengerjakan soal-soal tersebut; (4) jika dalam proses mempelajari kembali materi pelajaran yang diperolehnya dari sekolah subjek DHS menemukan adanya perbedaan isi materi, maka subjek DHS menggunakan penjelasan dari guru yang ada di dalam buku catatannya sebagai acuan dalam memahami materi; (5) subjek DHS memberikan tanda dalam buku referensinya (buku paket dan LKS) untuk menunjukkan materi yang tidak tertera pada buku catatannya; dan (6) subjek DHS mengikuti les sebagai salah satu upaya untuk lebih memahami materi pelajaran. 
Berbagai cara memperoleh pengetahuan yang dilakukan oleh subjek DHS tersebut, senada dengan pendapat yang dikembangkan oleh Francis Bacon (dalam Notoatmodjo, 2010: 10-18) bahwa dalam memperoleh kesimpulan dilakukan dengan mengadakan observasi langsung dan membuat pencatatan-pencatatan terhadap semua fakta sehubungan dengan objek yang diamati. Selain itu, dengan adanya kegiatan mempelajari kembali materi pelajaran yang dilakukan subjek DHS menunjukkan bahwa subjek DHS berusaha mencari sumber referensi lain baik internal maupun eksternal yang bisa mendukung pengetahuannya terhadap materi pelajaran. Sumber pemerolehan pengetahuan tersebut, sesuai dengan penjelasan Stapleton (2003: 43) bahwa membangun pengetahuan dimulai dengan mencari informasi-informasi yang dibutuhkan.

\section{Proses Membangun Pengetahuan Konseptual Subjek LNH, Sebagai Subjek Penelitian dengan Kemampuan Akademik Tinggi}

Berdasarkan penjelasan guru pada pelaksanaan pembelajaran berkaitan dengan materi unsur-unsur kubus dan 2 kali hasil wawancara yang dilakukan kepada subjek LNH, dapat diketahui adanya perbedaan antara penjelasan guru dengan uraian yang disampaikan subjek LNH ketika menjelaskan tentang unsur-unsur dalam sebuah kubus. Pada wawancara pertama, subjek LNH menyatakan bahwa kubus mempunyai 12 buah rusuk, 6 buah sisi, 8 buah titik sudut, 12 diagonal bidang, 4 diagonal rusuk, 4 diagonal ruang. Sementara pada wawancara kedua, subjek LNH menyatakan bahwa kubus mempunyai mempunyai 12 buah rusuk, 6 buah sisi, 8 buah titik sudut, 12 diagonal bidang, 4 diagonal ruang, dan 6 bidang diagonal. Perbedaan uraian yang disampaikan subjek LNH pada wawancara pertama dan wawancara kedua adalah: (1) subjek LNH mengganti diagonal rusuk dengan diagonal ruang. Penggantian ini adalah penggantian anggota dari masing-masing unsur yang disebutkan subjek ABS. Unsur diagonal ruang beserta anggotanya yang disampaikan subjek LNH pada wawancara pertama, diubah menjadi unsur diagonal ruang dengan anggota yang sama pada wawancara kedua. Sementara uraian tentang diagonal ruang yang disampaikan subjek LNH pada wawancara pertama beserta anggotanya dianggap sebagai bidang diagonal pada wawancara kedua; (2) subjek LNH menambahkan adanya bidang diagonal pada sebuah kubus.

Adanya perubahan uraian tersebut, mengindikasikan bahwa subjek LNH melakukan proses membangun pengetahuan konseptual pada materi unsur-unsur kubus dengan beberapa konsep antara lain titik sudut, sisi, rusuk, diagonal ruang, diagonal sisi, dan bidang diagonal. Berbeda dengan subjek ABS maupun subjek DHS, subjek LNH mempunyai cara yang berbeda dalam membangun pengetahuan berkaitan dengan konsep unsur-unsur kubus yang disampaikan oleh guru. Jika subjek ABS dan subjek DHS 
melakukan proses belajar kembali, maka subjek LNH melakukan diskusi dengan teman sejawat berkaitan dengan materi yang disampaikan guru pada pembelajaran matematika. Dalam proses diskusi tersebut, terjadi saling interaksi antar siswa sehingga siswa bisa saling mengemukakan pendapatnya. Selain melalui diskusi kelompok, subjek LNH juga mengerjakan soal-soal latihan secara individual. Walaupun soal-soal yang dikerjakan oleh subjek LNH lebih berkaitan dengan pengetahuan prosedural yaitu pengetahuan tentang penyelesaian masalah matematis, namun pengetahuan prosedural dalam menyelesaikan masalah tersebut tidak lepas dari pengetahuan konseptual yang harus dikuasai siswa sebelumnya.

Dalam melakukan diskusi dengan teman sebaya tersebut, subjek LNH berusaha mencari tahu lebih dalam informasi berkaitn dengan materi pelajaran. Senada dengan pendapat Stapleton (2003: 43-52) yang menjelaskan 10 langkah memperoleh pengetahuan dan salah satunya adalah cari. Cari maksudnya adalah proses membangun pengetahuan dimulai dengan mencari informasi-informasi yang dibutuhkan melalui berbagai sumber seperti kelompok sebaya.

Pada materi unsur-unsur balok, subjek LNH sebagai subjek penelitian dengan kemampuan akademik tinggi memiliki pengetahuan yang baik berkaitan dengan konsep pada materi unsur-unsur balok yang disampaikan guru. Dari 2 kali hasil wawancara yang dilakukan dengan subjek LNH, pada wawancara pertama subjek LNH menyampaikan unsur-unsur balok adalah mempunyai 12 buah rusuk, 6 buah sisi, 8 buah titik sudut, 12 diagonal bidang, 4 diagonal ruang dan 6 bidang diagonal. Pada wawancara kedua, unsurunsur balok yang disampaikan subjek LNH adalah balok mempunyai 12 rusuk, 6 sisi, 8 titik sudut, 12 diagonal bidang, 4 diagonal ruang, dan 6 bidang diagonal.

Berdasarkan 2 kali hasil wawancara tersebut, terlihat bahwa uraian yang disampaikan subjek LNH cenderung sama, bahkan subjek LNH memiliki pengetahuan yang berbeda dengan penjelasan yang disampaikan guru pada proses pembelajaran materi unsur-unsur balok. Adanya perbedaan uraian yang disampaikan oleh guru dan subjek LNH pada 2 kali kesempatan wawancara tersebut, menunjukkan bahwa subjek LNH tidak secara langsung menerima penjelasan dari guru sebagai pengetahuan baru yang tetap.

Secara keseluruhan cara yang dilakukan subjek ABS untuk lebih mengembangkan pengetahuannya berkaitan dengan materi unsur-unsur balok yang disampaikan guru pada proses pembelajaran matematika adalah: (1) subjek LNH memahami materi pelajaran dengan cara menyimak penjelasan dari guru saat pembelajaran berlangsung. Dalam proses menyimak materi pelajaran yang disampaikan guru saat pembelajaran berlangsung, subjek LNH membuat catatan-catatan untuk mengingatkan kembali pada materi tersebut; (2) subjek LNH juga melakukan diskusi 
kelompok untuk lebih memahami materi. Pada materi unsur-unsur balok subjek LNH berdiskusi tentang jaring-jaring pada balok beserta unsur-unsurnya; (3) subjek LNH mengerjakan soal-soal dengan melihat rumus serta cara penyelesaian soal tersebut pada buku panduan yang dimilikinya; (4) jika dalam membaca tersebut subjek LNH menemukan adanya perbedaan isi materi antara buku tersebut (buku paket dan LKS) dengan catatan yang dimilikinya, subjek LNH menjadikan buku paket yang paling lengkap sebagai panduan dalam belajar karena mudah dipahami; dan (5) subjek LNH mempelajari kembali materi pelajaran ketika mengikuti les di luar jam sekolah, kemudian mengerjakan latihan soal ketika les.

Berdasarkan proses membangun pengetahuan yang dilakukan ketiga subjek penelitian tersebut, dapat diketahui bahwa sebenarnya proses membangun pengetahuan konseptual harus dilakukan sendiri oleh siswa karena setiap siswa mempunyai cara yang berbeda dalam melakukan proses tersebut. Proses membangun pengetahuan berkaitan dengan suatu konsep dibangun sendiri oleh siswa. Dalam proses membangun pengetahuan tersebut, ketiga subjek melakukannya di dalam dan di luar lingkungan sekolah. Proses membangun pengetahuan dilakukan di dalam lingkungan sekolah dilakukan melalui proses pembelajaran di kelas yang diikuti oleh ketiga subjek penelitian dan di luar lingkungan sekolah melalui kegiatan les yang diikuti oleh ketiga subjek. Selain itu ketiga subjek penelitian juga mengerjakan tugas dari guru yang secara tidak langsung membuat pemahaman ketiganya menjadi lebih baik lagi.

Proses membangun pengetahuan erat sekali hubungannya dengan proses mengkonstruksi dalam filsafat konstruktivisme, sehingga proses membangun pengetahuan merupakan proses seseorang mengkonstruksi pengetahuan berdasarkan apa yang mereka terima. Dalam dimensi proses kognitif yang dikemukakan oleh Anderson dan Krathwohl (2010: 100-102), sebagai berikut: "Memahami (Mengkonstruksi makna dari materi pembelajaran, termasuk apa yang diucapkan, ditulis, dan digambar oleh guru)". Hal tersebut mengandung arti bahwa seseorang yang berusaha mengkonstruksi makna dari pembelajaran, termasuk apa yang diucapkan, ditulis, dan digambar oleh guru sebenarnya melakukan proses memahami materi tersebut. Selanjutnya Anderson dan Krathwohl (2010: 105), mengatakan bahwa siswa dikatakan memahami bila mereka mengkonstruksi makna dari pesan-pesan pembelajaran, baik yang bersifat lisan, tulisan ataupun grafis, yang disampaikan melalui pengajaran, buku, atau layar komputer. Merujuk dari pendapat Anderson dan Krathwohl tersebut, berarti terdapat banyak cara yang bisa dilakukan siswa untuk memahami suatu materi berkaitan dengan konsep yang disampaikan oleh guru. Senada dengan pendapat Hussain (dalam Hussain, 2012: 179) 
yang menggambarkan belajar sebagai suatu proses sosial yang terjadi di dalam dan di luar kelas.

Dalam penelitiannya Yin et al. (2013: 137), menyatakan bahwa berinteraksi dengan orang-orang di dunia nyata dapat meningkatkan pemahaman pengetahuan konseptual. Pengetahuan pendidik tidak hanya untuk menciptakan lingkungan belajar online bagi pelajar, tetapi juga perlu untuk memicu motivasi peserta didik untuk membangun pengetahuan mereka. Studi ini menunjukkan bahwa beberapa faktor mungkin sangat penting dalam membangun pengetahuan: otonomi pelajar, keterampilan komputer dalam akses web, dan menyukai lingkungan belajar online. Terutama otonomi pelajar harus diperlakukan sebagai faktor yang paling penting untuk mempengaruhi konstruksi pengetahuan peserta didik. Selain itu, keterampilan komputer juga telah diperlakukan sebagai faktor penting untuk meningkatkan otonomi pelajar di lingkungan online (Huang, 2007: 43).

\section{KESIMPULAN DAN SARAN}

Proses membangun pengetahuan konseptual yang diungkapkan dalam penelitian ini adalah proses membangun pengetahuan konseptual yang dilakukan siswa berkaitan dengan pengetahuan tentang klasifikasi dan kategori pada materi unsur-unsur kubus dan balok. Berdasarkan hasil analisis dan pembahasan data hasil penelitian dari tiga orang subjek penelitian dengan masing-masing kemampuan akademik tinggi, sedang, dan rendah di kelas VIII SMP Negeri 1 Kudus, diperoleh simpulan sebagai berikut.

Proses membangun pengetahuan konseptual pada subjek ABS dengan kemampuan akademik rendah di kelas VIII SMP Negeri 1 Kudus. Awalnya pengetahuan yang diperoleh subjek ABS berkaitan dengan materi yang disampaikan guru pada pembelajaran masih bersifat global. Artinya, subjek ABS hanya mengetahui unsur-unsur kubus dan balok tanpa mampu mengidentifikasi secara detail. Informasi dan pengetahuan lebih detail diperoleh subjek ABS ketika mengerjakan tugas dari guru untuk membuat jaring-jaring kubus dan balok serta mengidentifikasi unsur-unsurnya, yang dilakukan dengan cara: (1) memvisualisasikan bentuk kubus dan balok ke dalam bentuk benda lain di lingkungan sekitar untuk mengidentifikasi unsur-unsurnya; (2) membuat hubungan antara kubus dan balok dengan menganggap keduanya mempunyai unsur-unsur yang sama; (3) membuat kategori pengelompokkan bangun ruang (kubus dan balok) dengan melihat bentuk sisinya. Selain mengerjakan tugas dari guru, subjek ABS juga melakukan kegiatan lain, seperti: (1) mempelajari kembali materi pelajaran dengan membaca buku catatan dan referensi lain yang relevan seperti buku paket dan LKS (Lembar Kerja Siswa); (2) menggunakan buku/catatan yang paling lengkap sebagai acuan dalam belajar 
ketika menemukan perbedaan penjelasan tentang unsur-unsur kubus dan balok pada buku lain; (3) mengulang materi pelajaran pada saat mengikuti les di luar jam sekolah hanya dengan mendengarkan penjelasan dari guru les.

Proses membangun pengetahuan konseptual pada subjek DHS dengan kemampuan akademik sedang di kelas VIII SMP Negeri 1 Kudus. Awalnya pengetahuan yang diperoleh subjek DHS berkaitan dengan materi yang disampaikan guru pada pembelajaran masih bersifat global yaitu hanya mengetahui unsur-unsur kubus dan balok tanpa mampu mengidentifikasi secara detail bagian-bagiannya. Informasi dan pengetahuan lebih detail diperoleh subjek DHS melalui proses mengerjakan tugas yang diberikan oleh guru dengan melakukan beberapa cara/teknik, yaitu: (1) membuat hubungan antara kubus dan balok dengan menganggap keduanya mempunyai unsur-unsur yang sama; (2) mengidentifikasi bentuk sisi pada sebuah balok melalui contoh bangun ruang di lingkungan sekitar; (3) membuat kategori dalam pengelompokkan kubus dan balok dengan melihat bentuk sisinya. Selain mengerjakan tugas dari guru, subjek DHS juga melakukan kegiatan lain, seperti: (1) membaca kembali materi pelajaran serta mencari sumber referensi yang mendukung berupa buku paket dan LKS (Lembar Kerja Siswa) sebagai sumber belajar; (2) menggunakan materi yang diperoleh dari penjelasan guru pada saat proses pembelajaran berlangsung sebagai acuan dalam mempelajari materi pelajaran; (3) memberikan tanda jika terdapat perbedaan isi materi pada beberapa buku yang dipelajari seperti buku catatan, buku paket, dan LKS (Lembar Kerja Siswa); (4) jika subjek DHS menemukan soal latihan, maka subjek DHS melakukan hal berikut: (a) mengerjakan latihan soal yang berbeda dengan contoh dari guru; (b) tidak mengerjakan soal yang mempunyai cara penyelesaian sama dengan soal dari guru dan memahami cara penyelesaiannya saja; (5) mengikuti les di luar jam pelajaran sekolah dan bertanya jika belum mengerti.

Proses membangun pengetahuan konseptual pada subjek LNH dengan kemampuan akademik tinggi di kelas VIII SMP Negeri 1 Kudus. Awalnya pengetahuan yang diperoleh subjek LNH berkaitan dengan materi unsur-unsur kubus dan balok belum sedetail apa yang disampaikan guru saat pembelajaran di kelas. Dalam penjelasannya subjek LNH hanya mampu mengidentifikasi secara detail beberapa unsur yang ada pada kubus dan balok. Informasi dan pengetahuan lebih detail diperoleh subjek LNH ketika melakukan beberapa kegiatan dalam mengerjakan tugas yang diberikan oleh guru, yaitu: (1) melakukan diskusi dengan teman sebaya membahas tentang jaring-jaring kubus dan balok beserta unsur-unsurnya; (2) memvisualisasikan bentuk kubus dan balok ke dalam bentuk benda lain di lingkungan sekitar untuk mengidentifikasi unsur-unsurnya; (3) menentukan kriteria pengelompokkan bangun ruang (kubus dan balok) yaitu dengan 
melihat bentuk sisinya. Selain mengerjakan tugas dari guru, subjek LNH juga melakukan kegiatan lain, seperti: (1) membaca buku paket dalam mempelajari kembali materi pelajaran. Buku tersebut juga digunakan subjek LNH sebagai acuan ketika menemukan perbedaan penjelasan unsur-unsur kubus dan balok yang ada di catatan, buku paket, ataupun LKS (Lembar Kerja Siswa); (2) mengerjakan soal-soal latihan pada buku paket atau LKS (Lembar Kerja Siswa) dengan cara: (a) membaca buku untuk melihat rumusrumus yang digunakan; (b) melihat cara penyelesaian masalah pada buku panduan yang dimiliki; (3) mempelajari kembali materi pelajaran ketika mengikuti les di luar jam sekolah, mengajukan pertanyaan, dan mengerjakan latihan soal.

Berdasarkan simpulan yang telah dipaparkan, dapat disampaikan saran sebagai berikut: (1) Berdasarkan hasil penelitian, diketahui bahwa proses siswa membangun pengetahuan berkaitan dengan materi yang disampaikan guru dilakukan di kelas pada proses pembelajaran dan di luar kelas melalui berbagai usaha individual. Melihat hasil penelitian tersebut, pada proses pembelajaran di kelas, hendaknya guru melaksanakan pembelajaran dengan lebih menekankan keaktifan siswa untuk bertanya dan mengemukakan pendapat. Salain itu, guru juga bisa melakukan diskusi atau membentuk kelompok diskusi siswa. Tujuan dibentuk kelompok diskusi tersebut adalah untuk memudahkan siswa dalam belajar dan mengefektifkan pembelajaran di kelas. Selain itu, dengan adanya kelompok tersebut, siswa lebih leluasa dalam bertukar pikiran dengan anggota kelompoknya; (2) Dengan adanya kegiatan yang dilakukan siswa di luar jam pelajaran sekolah dalam upayanya membangun pengetahuan, hendaknya guru memberikan tugas untuk menjembatani siswa dalam belajar. Tugas-tugas yang diberikan guru harus menekankan pada pemahaman konsep siswa, tugas tersebut bisa berupa soalsoal latihan yang mengarah kepada identifikasi ciri-ciri sebuah kubus atau balok, membuat jaring-jaring kubus atau balok, memberikan definisi kubus dan balok, dan mencari benda-benda di lingkungan sekitar yang berbentuk kubus atau balok serta memberikan alasannya; (3) Penelitian ini hanya mengungkap proses membangun pengetahuan konseptual yang dilakukan siswa berkaitan dengan pengetahuan tentang klasifikasi dan kategori. Padahal, terdapat dua subjenis pengetahuan konseptual lainnya yaitu pengetahuan tentang prinsip dan generalisasi serta pengetahuan tentang teori, model, dan struktur yang tidak diungkapkan dalam penelitian ini. Oleh karena itu, peneliti menyarankan kepada peneliti lain untuk meneliti lebih lanjut proses membangun pengetahuan konseptual yang dilakukan siswa pada kedua subjenis tersebut. 


\section{DAFTAR PUSTAKA}

Anderson, L. W. dan Krathwohl, D. R. 2010. Kerangka Landasan untuk Pembelajaran, Pengajaran, dan Asesmen: Revisi Taksonomi Pendidikan Bloom. Yogyakarta: Pustaka Belajar.

Emereole, H. U. 2008. Correlates of Conceptual Knowledge of Science Processes with Some Demographic Variables of Undergraduate Students: The Case of University of Botswana. Journal of Baltic Science Education. ISSN 1648-3898. 2008, Vol.7, No.1, p:5-16. [Online]. Tersedia: http://www.jbse.webinfo.lt/jbse_2008_vol.7_No.1.htm (23 Juli 2013).

Emereole, H. U. 2009. Learners' and Teachers' Conceptual Knowledge of Science Processes: The Case of Botswana. International Journal of Science and Mathematics Education. 7: 1033-1056. [Online]. Tersedia: http://link.springer.com/article/ 10.1007\%2Fs10763-008-9137-8 (14 Mei 2013).

Huang, H. 2007. Predicting Knowledge Construction in the Web-Based Learning Environment. International Journal of Instructional Media. 34.4 (Fall 2007): p431-440. From Gale Education, Religion and Humanities Lite Package.

Hussain, I. 2012. Use of Constructivist Approach in Higher Education: An Instructor's Observation. Creative Education. Vol. 3 No.2 178-184: From Gale Education, Religion and Humanities Lite Package.

Nievelstein, F., Gog, T., Boshuizen, H. P. A., dan Prins, J. A. 2010. Effects of Conceptual Knowledge and Availability of Information Sources on Law Students' Legal Reasoning. Instructional Science. Volume 38, Januari 2010: 23-35.

Notoatmodjo, S. 2010. Metodologi Penelitian Kesehatan. Jakarta: PT Rineka Cipta.

Powell, K. C. dan Kalina, C. J. 2009. Cognitive and Social Constructivism: Developing Tools for an Effective Classroom. Education 130.2 p:241-250. From Gale Education, Religion and Humanities Lite Package.

Stapleton, J. J. 2003. Executive's Guide to Knowledge Management the Last Competitive Advantage. New Jersey: John Wiley \& Sons, Inc.

Sultan, W. H., Charles, P. W. dan Koo, A. 2011. A Constructivism Approach for Digital Learning: Malaysian Schools Case Study. Educational Technology and Society. 14(4), 149-163.

Yin, C., Song, Y., Tabata, Y., Ogata, H., dan Hwang, G-J. 2013. Developing and Implementing a Framework of Participatory Simulation for Mobile Learning Using Scaffolding. Educational Technology \& Society. 16(3), p:137-150. From Gale Education, Religion and Humanities Lite Package. 